\title{
THE CHINESE LIZARDS OF THE GENUS GEKKO
}

\author{
By Leonhard Stejneger
}

Head Curator, Department of Biology, United States National Museum

The recent accession of material by the National Museum has helped clear up several doubtful points in the taxonomy and distribution of the lizards belonging to the genus Gekko, so that a summary of our present knowledge of this interesting group may not be out of place.

\section{Genus GEKKO Laurenti}

1768. Gekko Laurenti, Syn. Rept., p. 43 (type, G. verticillatus Laurenti= Lacerta gecko Linnaeus).

1792. Stellio SchneIder, Amph. Physiol., vol. 2, p. 2 (type, S. gecko; not of Laurenti).

1800. Gecko Cuvier, Leçons d'Anat. Comp., vol. 1, tabl. III (emendation).

1810. Gecus Rafinesque, Caratteri, p. 9 (emendation).

1817. Ascalabotes Cuvier, Règne Animal, vol. 2, p. 44 (subst. for Stellio Schneider).

1817. Platydactylus Oken, Isis, 1817, p. 1183 (based on "Platy-Dactyles" Cuvier, 1817 ; type designated in 1843 by Fitzinger, G. guttatus Daudin).

1833. Somatodactylus VAN DER HoEven, Handb. Dierk., vol. 2, pt. 2, p. 342 (type, G. vittatus Houttuyn).

1843. Scelotretus FitzINGER, Syst. Rept., p. 101 (type, G. vittatus).

KEY TO CHINESE SPECIES AND SUBSPECIES OF GEKKO

$a^{1}$. Rostral not entering nostril gecko

$a^{2}$. Rostral entering nostril.

$b^{1}$. No web at base of toes, or a mere trace.

$c^{1}$. Dorsal tubercles numerous, usually more or less evenly distributed on the back to and often invading occiput.

$d^{1}$. On each side of base of tail normally 2 or 3 tubercles close together, or a cluster of smaller tubercles (occasionally only one large) japonicus

$d^{2}$. On each side of base of tail normally a single large tubercle japonicus hokouensis

$c^{2}$. Dorsal tubercles less numerous, especially on the anterior half of the back and rarely invading occiput swinhonis

$b^{2}$. A distinct web at base of toes.

$c^{1}$. Back without tubercles; male with 9 to 11 preanal pores. $d^{1}$. Back grayish, uniform or with obscure dark markings or cross bands subpalmatus $d^{2}$. Back with distinct dark, broad cross bands_-_-_-_subpalmatus melli

$c^{2}$. Back with numerous small tubercles; males with 17 or more preanal pores in one row chinensis 


\section{GEKKO GECKO (Linnaeus)}

1758. Lacerta gecko Linnaeus, Syst. Nat., ed. 10, vol. 1, p. 205 (type locality, "in Indies").-Gekko gecko Barbour, Mem. Mus. Comp. Zoöl., vol. 44, 1902, p. 82.-Gecko gecko Mru, Grundz. Oekol. Chines. Rept., 1929, p. 11 (Indomalayan).-AнL, Sitz. Ber. Ges. Naturf. Freunde, Berlin, 1929 (1930), p. 327 (Kiangsi).

1768. Gekko verticillatus Laurenti, Syn. Rept., p. 44 (based on "Seba, I. 108. $2 \& 6$ \& 7 ").-GEe, Peking Soc. Nat. Hist. Bull., vol. 4, pt. 2, 1929, p. 57 (Kwangtung, Kwangsi).-Gecko verticillatus Boulenger, Cat. Liz. Brit. Mus., vol. 1, 1885, p. 183 (southern China, etc.).-BoEтTGer, Offenbach. Ver. Naturk., 24-25 Ber., 1885, pp. 117, 140 (Canton; Kwangsi) ; 26-28 Ber., 1888, p. 61 (Canton).-Werner, Abh. Bayer. Akad. Wiss., Kl. 2, vol. 22, pt. 2, 1903, p. 360.-Stanley, Journ. North China Asiat. Soc., vol. 45, 1914, p. 25 (southernmost China).-Vogt, Sitz. Ber. Ges. Naturf. Freunde, Berlin, 1914, p. 97 (Wu-tsung, near Canton).-MELL, Arch. Naturg., vol. 88, sect. A, pt. 10, Dec., 1922, p. 111 (Kwangtung; Lolong; Lofausan; Ding-wu-san ; Tseberg, north distr.)

1768. Gekko teres Laurenti, Syn. Rept., p. 44 (based on “Seba, I, 108. 1 \& 3 ”). 1803. Gecko guttatus Daudin, Hist. Nat. Rept., vol. 4, p. 122, pl. 49 (type locality unknown).-GüNTHER, Rept. Brit. India, 1864, p. 102 (southern China).-Platydactylus guttatus Duméril and Bibron, Erp. Gén., vol. 3, 18, p. 328, pl. 28, fig. 4 (India; Java; Timor; Manila, Philippine Islands). 1820. Gekko versus Merrem, Tent. Syst. Amph., p. 42 (in "Archipelago Indico"; based on "Seba Thes. I. t. 108").

1820. Gecko annulatus KUHL, Beitr. Zool. vergl. Anat., pt. 1, p. 132 (type locality unknown).

1831. Gecko reevesii GraY, in Griffith, The animal kingdom, vol. 9, Syn., p. 48 (type locality [Canton] China; type in Brit. Mus., J. Reeves, collector).Platydactylus reevesii Fttzinger, Syst. Rept., 1843, p. 101 (China).

1858. Gekko indicus GIRARD, Herp. U. S. Expl. Exped., p. 290, pl. 16, figs. 9-16 (type locality, Mangsi Isl., Philippine Islands; type U.S.N.M. No. 5681).

1927. Gekko gekko Sснмпт, Bull. Amer. Mus. Nat. Hist., vol. 54, p. 479 (Yunnan-fu? or Tonkin) (emendation).-GEe, Peking Soc. Nat. Hist. Bull., vol. 4, pt. 2, 1929, p. 57 (Yunnan; Tonkin).

The locality Yunnan-fu for this species seems extremely doubtful, as admitted by Schmidt. The United States National Museum has no specimen from Chinese territory. It seems to be confined to Kwangsi and Kwangtung, and has not even been recorded for Hainan.

\section{GEKKO JAPONICUS (Duméril and Bibron)}

1836. Platydactylus japonicus DumérIL and Brbron, Erp. Gén., vol. 3, p. 337 (type locality, Japan; types in Paris Mus.).-Gecko japonicus GüNTHER, Rept. Brit. India, 1864, p. 103 (southern Japan; China; Formosa).Boulenger, Cat. Liz. Brit. Mus., vol. 1, 1885, p. 188 (Japan; China: Chefu, Shanghai, Ningpo, etc.) ; vol. 3, 1887, p. 488 (Ichang, China; Riukiu Archipelago).-Boettger, Ber. Senckenberg. Naturf. Ges., 1894, p. 143 (Shanghai).-Werner, Abh. Bayer. Akad. Wiss., Kl. 2, 1903, p. 300 (China).-Elpatiewsky and Sabanejew, Zool. Jahrb. Syst., vol. 24, 1906, p. 250 , pl. 18, fig. 1 (Bukhti Sv. Olgi i Sv. Vladimira, Ussuri, probably introduced).-Nikolski, Fauna Rossij, Rept., vol. 1, 1915, p. 93 (part: 
Japan; Chefu).-Gekko japonicus SteJneger, Journ. Sci. Coll. Tokyo, vol. 12, pt. 3, p. 218 (Formosa) ; Herpet. Japan, 1907, p. 165, pl. 13 (Japan, Korea, China) ; Proc. U. S. Nat. Mus., vol. 66, art. 25, 1925, p. 37 (Kiangyin, Kiangsu ; Hankow; Hunan).- van Denburgh, Proc. California Acad. Sci. ser. 4, vol. 3, Dec. 16, 1912, p. 106 (Shanghai, Formosa; Riukiu).-JACOT, China Journ. Sci. Arts, vol. 1, 1923, p. 259 (Chefoo) ; Peking Nat. Hist. Bull., vol. 5, pt. 3, 1931, p. 42 (Shansi : Kolan; Shantung).-ScH midT, Bull. Amer. Mus. Nat. Hist., vol. 54, 1927, p. 477 (Fukien, Anhwhei, Hunan).GeE, Peking Nat. Hist. Soc. Bull., vol. 4, pt. 2, Dec., 1929, p. 57 (part).

1838. Platydactylus jamori Temminck and Schlegel, Fauna Japon., Rept.,

p. 103 (type locality, southern Japan; types in Leyden Mus.; Siebold, collector).

1842. Hemidactylus nanus Cantor, Ann. Nat. Hist., vol. 9, Aug., 1842, p. 482 (Chusan).

1891. Platydactylus yamori Fritze, Mitth. Deutsch. Ges. Ost-Asiens, vol. 5, p. 239 (emendation).

1902. Gehyra intermedia Brown, Proc. Acad. Nat. Sci. Philadelphia, June 11, 1902, p. 183 (type locality, probably Okinawa Shima, Riukiu; type, Wistar Inst. No. 572; Furness and Keller, collectors).

A number of specimens from Shanghai (U.S.N.M. Nos. 67035-38 and 73188) add little to our knowledge of this form. Their dorsal lepidosis is normal; the male (No. 67035) has eight preanal pores in a continuous row, and three well-developed basicaudal tubercles. The young, No. 73188, has also three small such tubercles; in the others they are represented by clusters of smaller tubercles.

\section{GEKKO JAPONICUS HOKOUENSIS Pope}

1928. Gelko japonicus hokouensis Pope, Amer. Mus. Nov., no. 325, Sept. 15, 1928, p. 1 (type locality, Hok'ou [Hokow], northeast Kiangsi, China; type, Amer. Mus. Nat. Hist. No. 35090; C. H. Pope, collector) ; Bull. Amer. Mus. Nat. Hist., vol. 58, p. 365, fig. 1 (northeast Kiangsi; Chunganhsien, Fukien).-GeE, Peking Soc. Nat. Hist. Bull., vol. 4, pt. 2, Dec., 1929, p. 57.

This form has been separated from $G$. japonicus on the strength of the large single tubercular scale at the base of the tail. In 13 topotypes recorded by Mr. Pope it was single on both sides; in the fourteenth specimen it was divided on one side.

By referring to my Herpetology of Japan, p. 168, it will be seen that this feature is subject to great variation in true $G$. japonicus, even in Japan, where specimens with large single tubercles are not uncommon. However, in most of the specimens, both in Japan and on the mainland, especially in the lowlands of the lower Yangtse Basin, the number ranges from 1, 2, or 3 larger tubercles to clusters of smaller tubercles, as attested by 12 specimens in the National Museum, from the Kiangsu, Hupeh, and other Provinces.

The type material of the present form comes from a plateau on the boundary between Fukien and Kiangsi. The Museum of Com- 
parative Zoölogy has a large series of specimens from Tunglu, about 165 miles to the northeast in the neighboring Province of Chekiang, collected by J. T. Wright. Thanks to the kindness of Dr. Thomas Barbour, 10 of these are in the National Museum (Nos. 78193-202), and in every one of them the tubercle is single and large, somewhat of the shape of the "shovel" on the metatarsal tubercle of certain toads. In some of the specimens there is evidence of its origin in a consolidation of three smaller tubercles. ${ }^{1}$ These specimens from Chekiang are otherwise identical with the average Yangtse basin specimens, except that perhaps more specimens of the former show a tendency toward the dorsal tubercles being less numerous on the middle of the back than in the former. Similar specimens occur also in our series from Japan and Korea. As a consequence I am unable to distinguish these Kiangsi-Chekiang specimens with a single basicaudal tubercle from a number of Japanese and Chinese specimens of typical $G$. japonicus. Nevertheless, in view of the large number of individuals in the region where the three Provinces of Kiangsi, Fukien, and Chekiang meet, displaying this character, I consider it expedient to recognize this form trinominally at least until further researches shall have evaluated the importance of this character. I am the more inclined toward this procedure by a consideration of the fact that in all our specimens of $G$. subpalmatus the tubercle in question is large and single.

Owing to the comparative nearness of Chusan, the type locality of Cantor's Hemidactylus nanus (Ann. Nat. Hist., vol. 9, Aug., 1842, p. 482), I requested Mr. Parker to examine the type in the British Museum with regard to the basicaudal tubercles, and he kindly informs me that there are three on each side of the base of the tail. The name therefore seems to be an unconditional synonym of $G$. japonicus, as represented by the Shanghai specimens, and does not interfere with the nomenclature of the form here considered.

\section{GEKKO SWINHONIS Günther}

1864. Gecko swinhonis GüNTHeR, Rept. Brit. India, p. 104, pl. 12, fig. A (type locality, Peking, China; type in Brit. Mus.; R. Swinhoe, collector).Boulenger, Cat. Liz. Brit. Mus., vol. 1, 1885, p. 189 (Peking).-MüLler, Verh. Naturf. Ges. Basel, vol. 7, pt. 3, 1885, p. 709 (Tientsin).-Gekko swinhonis Stejneger, Herpet. Japan, 1907, p. 166 (northern China) ; Proc. U. S. Nat. Mus., vol. 66, art. 25, 1925, p. 36 (Chili ; Kansu; Shensi ; Shantung; Tientsin to Peking).-Barbour, Proc. New England Zoöl. Club, vol.

\footnotetext{
${ }^{1}$ Dr. Thomas Barbour has kindly examined the remaining series of 25 specimens in the Museum of Comparative Zoölogy. He summarizes the result as follows: "I would define the Tunglu lot as characterized by having, in the adult males, invariably a single, elongate, shovel-shaped tubercle derived from the coalescence of two rudiments which occasionally persist as independent papillae in young specimens and of these larger in females than in males."
} 
4, Nov., 1909, p. 61 (Sian, Shensi).-Van Denburgh, Proc. California Acad. Sci., ser. 4, vol. 3, Dec. 16, 1912, p. 207 (Chefu).-ЈАсот, China Journ. Sci. Arts, vol. 1, 1923, p. 259 (Shantung) ; Peking Nat. Hist. Bull., vol. 5, pt. 3, 1931, p. 42 (Tsinan, Shantung, in the hills).-Schmidt, Bull. Amer. Mus. Nat. Hist., vol. 54, 1927, p. 1927, p. 478 (Chihli; Shansi).-Pope, Bull. Amer. Mus. Nat. Hist., vol. 57, 1929, p. 368 (Chili ; Shansi).Gee, Peking Soc. Nat. Hist. Bull., vol. 4, pt. 2, 1929, p. 57 (North China; Chihli; Shansi).

1885. Gecko swinhoei BoETtGer, Offenbach. Ver. Naturk., 24-25 Ber., p. 139 ; 26-28 Ber., 1888; p. 61 (Miau-feng-shan, near Peking) ; Kat. Rept. Mus. Senckenberg, vol. 1, 1893, p. 35.-Werner, Abh. Bayer. Akad. Wiss., Kl. 2, vol. 22 , pt. 2 , 1903 , p. 360 .

1887. Gecko japonicus Moellendorf, Journ. North China Asiat. Soc., new ser., vol. 11, p. 104 (Chili) (not of Duméril and Bibron).-Sow ERBY, in Clark and Sowerby, Through Shen-Kan, 1912, p. 111 (Kansu; Shensi).

A series of 27 specimens collected by F. R. Wulsin for the National Geographic Society (U.S.N.M. Nos. 628210-26) at Peking agrees with those previously recorded. The males have 7 to 9 preanal pores, mostly 9 , in an uninterrupted series. The basicaudal tubercles are usually 2 or 3 , mostly 3 , on each side or, less often, clusters of smaller tubercles.

\section{GEKKO SUBPALMATUS Günther}

1864. Gecko subpalmatus GÜNther, Rept. India, p. 104, pl. 12, fig. B (type locality, "Chikiang," China; type in Brit. Mus.; Robert Fortune, collector).-Boulenger, Cat. Liz. Brit. Mus., vol. 1, 1885, p. 189 (Chikiang) ; Proc. Zool. Soc. London, 1899, p. 160 (Kuatun, Fukien).-BoEtTGER, Offenbach. Ver. Naturk., 24-25 Ber., 1885, p. 139 (Chikiang) ; 26-28 Ber., 1888, p. 116 (Tschekiang).-Werner, Abh. Bayer. Akad. Wiss., Kl. 2, vol. 22, pt. 2, 1903, p. 360.-Gekko subpalmatus Stejneger, Proc. U. S. Nat. Mus., vol. 66, art. 25, 1925, p. 35 (part: Suifu, Szechwan).-Sснміdт, Bull. Amer. Mus. Nat. Hist., vol. 54, 1927, p. 478 (Yenping, Fukien; Wanhsien, Szechwan).-Pope, Bull. Amer. Mus. Nat. Hist., vol. 58, 1929, p. 367 (Yenping and Ch'ungan Hsien, Fukien).-GEE, Peking Soc. Nat. Hist. Bull., vol. 4, pt. 2, 1929, p. 57 (Chekiang, Fukien, Szechwan).

The locality given for the type of G. subpalmatus is "Chikiang, China," and the collector's name "Mr. Fortune." The latter is undoubtedly the celebrated traveler Robert Fortune, who in the later forties and early fifties of the nineteenth century made several visits to the tea districts of eastern China, collecting plants and information regarding the tea industry.

Definite localities for this form have not been established outside the Provinces of Fukien and Szechwan, and when specimens from the latter were first received it was surmised that the locality "Chikiang" referred to some place in that Province. However, it appears certain that Mr. Fortune did not reach Szechwan, nor even Chikiang in Hupeh, about 80 miles south of Ichang. Most of his travels in what was then called "northern China" were in the tea 
districts of Ningpo and other places of the Province of Chekiang. It has therefore been generally supposed that "Chikiang" was an error for Chekiang. While there is no definite record of any specimen having as yet been taken in that Province, it is, of course, not excluded that it may occur in the higher mountain districts of the interior near the western frontier. As a matter of fact, Mr. Fortune in the summer of 1849 undertook a voyage to the "Bohea Mountains" (Wuyi shan) in Fukien, which took him through the whole length of Chekiang into the mountain region where Chekiang, Kiangsi, and Fukien meet. ${ }^{2}$ Among other places he stopped at Ch'ungan Hsien, Fukien (or Tsong-gan-hien, as he spells it), where Mr. Pope 76 years later obtained two specimens of this same form. ${ }^{3}$ Most likely, therefore, it was in this very mountainous region, which extends across the boundary into Chekiang, that the type specimen of G. subpalmatus was collected.

This seems to be the only form occurring in the region about Suifu, Szechwan, from which locality Dr. D. C. Graham has recently sent additional specimens (U.S.N.M. Nos. 67571, 69467, 76586, and 76589). Like those previously received, they are quite typical, with no dorsal tubercles, and a single large tubercle on each side of the base of the tail. The fingers are distinctly webbed at the base as well as the toes, a feature particularly well shown in No. 76589 .

\section{GEKKO SUBPALMATUS MELLI (Vogt)}

1922. Gecko melli Vogt, Arch. Naturg., vol. 88, sect. A, pt. 10, p. 136, pl. 4, fig. 2 (type locality, mountains of northeastern Kwangtung, 500-800 meters altitude).-Meld, Arch. Naturg., vol. 88, sect. A, pt. 10, p. 111.-Gekko melli GEe, Peking Soc. Nat. Hist. Bull., vol. 4, pt. 2, 1929, p. 57 (Kwangtung).

The Gekko melli from Kwangtung, described in 1922 by Doctor Vogt, does not seem to differ materially from $G$. subpalmatus except perhaps in the intensity of the broad dark bands across the back, which, if constant, may justify the subspecific appellation Gekko subpalmatus melli (Vogt).

\section{GEKKO CHINENSIS Gray}

1842. Gecko chinensis GraY, Zool. Misc., p. 57 (type locality, China; type in Brit. Mus.; J. Reeves, coll.).

1885. Gecko japonicus BoETTGER, Offenbach. Ver. Naturk., 24-25 Ber., p. 117 (environs of Canton, China) (not of Duméril and Bibron) ; 26-28 Ber., 1888, p. 60 (Ding-her-shan, Kwantung).

1923. Gekko similignum Sмгтн, Journ. Nat. Hist. Soc. Siam, vol. 6, Oct. 31, 1923, p. 198 (type locality, Ang-mao, 600 meters altitude, near Five Finger Mountain, Hainan; type in Brit. Mus.; Malcolm Smith, coll.).-ScH midr, Bull. Amer. Mus. Nat. Hist., vol. 54, 1927, p. 461 (Hainan).

2 Two visits to the tea countries of China, ed. 3, vol. 2, pp. 125-273. London, 1853.

${ }^{8}$ Bull. Amer. Mus. Nat. Hist., vol. 58, 1929, p. 367. 
1925. Gekko subpalmatus? Stejneger, Proc. U. S. Nat. Mus., vol. 66, art. 25, p. 36 (part: Foochow, Fukien; U. S. N. M. No. 65379; A. de C. Sowerby, collector) (not of Günther).

1929. Gekko semilignum GEe, Peking Soc. Nat. Hist. Bull., vol. 4, pt. 2, p. 57 (emendation; Hainan).

In my previous paper ${ }^{4} \mathrm{I}$ referred to a specimen in the National Museum (No. 65379) as follows:

Among Sowerby's Fukien material there is also a gecko collected by him at Foochow. As far as the web of the feet is concerned, it is a typical $G$. subpalmatus, but the back is regularly covered with small though distinct tubercles, and the median chin shields are rather well developed. * * * I am therefore strongly inclined to the belief that the tubercles of the Sowerby specimen are the result of admixture of $G$. japonicus blood.

Since writing the above, Malcolm Smith's description of his new species from Hainan came to hand, and apparently my suggestion of the hybrid origin of the Fukien specimen became negatived, since the latter agrees point for point with the description of Malcolm Smith's specimen. Gekko similignum is characterized by having the back with about 10 irregularly disposed longitudinal rows of enlarged, rounded tubercle; the fingers one-third webbed, toes a little more; 17 preanal pores; 12 to 14 lamellae under fourth finger and a single large tubercle on either side of the base of the tail.

The Foochow specimen has a web between the fingers at their base, though not so conspicuous as that between the toes, agreeing in both respects with $G$. semipalmatus. Whether the fingers may be characterized as "one-third webbed" is perhaps doubtful, but such comparisons are quite vague, and a more definite description impracticable. It has 23 preanal pores in a continuous series; 13 lamellae under fourth fingers and toes; the tubercles on the back can hardly be said to form series, but there are about 10 in a line across the sides and back; the tubercle at the base of the tail is large and single as in G. subpatmatus.

The combination of tubercles on back with webbing between fingers and toes, and the high number of preanal pores, which normally varies between 4 and 11 in the other Chinese geckos of the same genus, seemed to indicate that we had to do with a distinct form, extending from Hainan north into Fukien. The relationships to G. palmatus from Tonking may not be made clear until a male of the latter is obtained.

Recalling that Boettger, in 1885 and 1888, had recorded two specimens from Kwangtung under the name of Gecko japonicus, but with 22 and 19 preanal pores, respectively, while the normal number of pores in that species varies between 4 and 11, and also that the type of Gray's Gecko chinensis in the British Museum was based

${ }^{4}$ Proc. U. S. Nat. Mus., vol. 66, art. 25, 1925, p. 36. 
on a specimen collected by J. Reeves probably near the same city, I sent our Fukien specimen to Dr. H. L. Parker and asked him to compare it with the types of $G$. chinensis and $G$. similignum. $\mathrm{He}$ very obligingly did so and wrote me as follows:

I have compared [U.S.N.M.] 65379 with the type of G. chinensis and G. similignum and I have very little doubt that the three are conspecific; Mr. Smith has seen them and agrees. Whether or not this represents a species distinct from G. japonicus I would not care to decide offhand. On the face of our material it appears so, but quite possibly they are only races of the same thing.

It may thus be regarded as established that there exists in southern China, from southern Fukien to Hainan, a distinct form characterized by the large number of 17 to 23 preanal pores (No. 65379= 23 ; Boettger's specimens $=22$ and 19 ; type of chinensis $=21$; type of similignum $=17$ ) besides the more extensive webbing of fingers and toes, as compared with the 4 to 11 pores, and more vestigial webbing in typical $G$. japonicus. 


\section{$2 \mathrm{BHL}$ Biodiversity Heritage Library}

Stejneger, Leonhard. 1932. "The Chinese lizards of the genus Gekko." Proceedings of the United States National Museum 82(2944), 1-8. https://doi.org/10.5479/si.00963801.2944.

View This Item Online: https://www.biodiversitylibrary.org/item/32567

DOI: https://doi.org/10.5479/si.00963801.2944

Permalink: https://www.biodiversitylibrary.org/partpdf/8981

\section{Holding Institution}

Smithsonian Libraries

\section{Sponsored by}

Smithsonian

\section{Copyright \& Reuse}

Copyright Status: NOT_IN_COPYRIGHT

Rights: https://www.biodiversitylibrary.org/permissions/

This document was created from content at the Biodiversity Heritage Library, the world's largest open access digital library for biodiversity literature and archives. Visit BHL at https://www.biodiversitylibrary.org. 